\title{
On Interpreting Strategies of Culture-Loaded Words from the Perspective of Linguistic Memetics
}

\author{
Hui Zhang \\ Nanchang Vocational University, Nanchang, China \\ Email: zhanghui4726@foxmail.com
}

How to cite this paper: Zhang, H. (2021). On Interpreting Strategies of Culture-Loaded Words from the Perspective of Linguistic Memetics. Open Journal of Modern Linguistics, 11, 688-702.

https://doi.org/10.4236/ojml.2021.114054

Received: July 28, 2021

Accepted: August 24, 2021

Published: August 27, 2021

Copyright $\odot 2021$ by author(s) and Scientific Research Publishing Inc. This work is licensed under the Creative Commons Attribution International License (CC BY 4.0).

http://creativecommons.org/licenses/by/4.0/

\section{(c) (i) Open Access}

\begin{abstract}
Culture-loaded words, with distinct cultural features, lead to lexical gaps for linguistic memes during transmission, which brings daunting challenges to interpreters. Despite various earlier studies of culture-loaded words conducted mainly from the perspective of functional equivalence, relevance theory, interpretive theory or ecological translatology, few are carried out from the perspective of linguistic memetics. For that reason, this paper constructs a Chinese-English interpreting corpus. Based on the corpus analysis method, it first retrieves all qualified culture-loaded words and classifies them into three categories from the perspective of linguistic memetics according to their representation information and content: form-meaning compound culture-loaded words (FMCWs), pronunciation derived culture-loaded words (PDWs) and culture-loaded words derived from morphological structures (MSDWs). Then it explores the interpreting strategies adopted for all culture-loaded words under the guidance of linguistic memetics, and finally summarizes the main interpreting strategies of FMCWs, PDWs, and MSDWs respectively on the basis of applied frequencies. The result shows that our study, compared with predecessors, presents more targeted and practical solutions for interpreters and brings fresh perspective for further studies.
\end{abstract}

\section{Keywords}

Culture-Loaded Words, Linguistic Memetics, Interpreting Strategies

\section{Introduction}

Culture-loaded words or culture-specific words are also called lexical gaps, that is, there are no equivalent words in the target language due to unique culture in- 
formation (Bao \& Bao, 2004). They can be words, phrases, idioms, and allusions that convey cultural connotations or associations and thus cannot be found in other languages or cultures. Baker (2000) proposed that the concepts expressed by some words in the source language are completely unfamiliar to the target audience. These concepts are either abstract, such as words reflecting religious beliefs or social customs, or are specific, such as special local snacks.

Remarkable progress has been made in previous studies on culture-loaded words from the perspective of memetics, though the classification of culture-loaded words either applied the idea of Nida (1998) or He et al. (2014). The former classified culture-loaded words into five categories, namely ecological culture-loaded words, material culture-loaded words, social culture-loaded words, religious culture-loaded words and linguistic culture-loaded words. The latter based on Blackmore's (2000) idea divided culture-loaded words into two types-genotype culture-loaded words and phenotype culture-loaded words. Despite a solid foundation it has laid for subsequent studies, that classification only focused on the cultural information of culture-loaded words and thus offered limited guidance for interpreting.

Meme is a basic unit of cultural evolution (Dawkins, 1976). Since he warned the powerful influence of the "selfish" meme (Dawkins, 1981), many researchers have carried out many in-depth studies (Dennett, 1990; Heylighen, 1992; Wang \& Yu, 2011; Distin, 2014). Blackmore (1999) defined that meme is any information that can be copied through the process of broad imitation. It is closely intertwined with language. As a culture gene, meme must have a carrier in order to survive. Language itself is a meme that is embodied in language. Since the concept was developed, it has aroused great interests among the academia in which more in-depth researches have been carried out (He et al., 2007; Chesterman, 2012; He, 2017) and thus the theory of memetics was created. It involves the systematic thought of meme as a unit of cultural representation and the reproduction, transmission and evolution mechanism under the system ( $\mathrm{He}$ et al., 2014). As a new theory based on Darwin's biological evolution, it sheds light on the law of cultural evolution. From the perspective of memetics, since language itself is a kind of meme, those memes which are passed on through language are called linguistic memes. Similarly, linguistic memetics is the systematic thought of linguistic meme and its reproduction, transmission and evolution mechanism. Based on the linguistic similarity and the role in the spread of culture, we can safely deem culture-loaded words as linguistic memes.

Since Chesterman combined memetics with translation studies, many researchers followed suit by applying this theory to the translation of culture-loaded words. Nonetheless, studies conducted in the field of interpreting are rare. Rarer are studies on the classification of culture-loaded words from the perspective of linguistic memetics. The application of linguistic memetics can strike a good balance between the speaker, the interpreter and the target language audience, achieving the purpose of smooth communication and thus facilitating cultural transmission. 
Linguistic memetics fundamentally regards the spread of culture-loaded words as a way of meme transmission, which undergoes four stages namely assimilation, retention, expression and transmission. To some extent, it provides some fresh insight into the interpreting of culture-loaded words.

The annual Premier's Press Conference at the "Two Sessions", under the spotlight of the global media, witness massive creation of culture-loaded words which are tinted with national features and thus bring daunting challenges to interpreters. Furthermore, interpreting studies of culture-loaded words from the perspective of linguistic memetics are rare.

Thus, there are three inadequacies of relevant studies on the translation of culture-loaded words: research perspective, research subject and research method. On research perspective, few studies were carried out from the perspective of linguistic memetics; on research field, the interpretation of culture-loaded words were rarely studied; on research method, cases analysis were largely used, offering limited guidance for interpreters.

The present study, taking account of these inadequacies, strives to construct a sub-corpus of Chinese-English consecutive interpreting of Premier's Press Conference at the "Two Sessions" from 2017 to 2019. Based on the corpus analysis method, this paper first, retrieves all qualified culture-loaded words conforming to the self-defined criteria of culture-loaded words and classifies them into three categories according to their representation information and content: form-meaning compound culture-loaded words (FMCWs), pronunciation derived cultureloaded words (PDWs) and culture-loaded words derived from morpho-logical structures (MSDWs). Then it explores the interpreting strategies of culture-loaded words from the perspective of linguistic memetics, and finally summarizes the main interpreting strategies of FMCWs, PDWs, and MSDWs respectively depending on their applied frequencies. It aims to provide targeted and practical solutions for interpreters and offer new thoughts for future studies in this regard.

\section{On the Interpreting of Culture-Loaded Words}

Since the "culture turn" was proposed (Bassnett \& Lefevere, 1990), it has torrentially swept across the field of translation studies (Tomalin \& Stempleski, 1994; Toury, 1995; Hermans, 2004). It has been stated (Nida, 1998; Bao \& Bao, 2004) that the translation of culture-loaded words presents a huge challenge for translators since there are no equivalent words in the target language. Various studies were carried out on the translation of culture-loaded words. Yet such studies were largely confined to translation filed (Chen, 2010; Ji \& Shi, 2010; Guo, 2011; Yao, 2013; Shiryaeva \& Badea, 2014; Wang \& He, 2014; Li, 2017; Zhe, 2017; Ye, 2018; Fan, 2018; Huang \& Yan, 2018). Specifically, on the translation strategies, Yao (2013) concluded that communicative translation strategies and semantic translation strategies should be properly applied in poetry translation. Ye (2018) proposed literal translation for genotype culture-loaded memes, free translation, imitation translation or even zero-translation for phenotype culture-loaded memes. 
As was stated (Gile, 1995) that interpretation would take almost all mental energy, and sometimes was more than available. Of few studies on the interpreting strategies of culture-loaded words (Song, 2012; Zhang, 2015; Liu, 2017; Sun, 2017; Zhu, 2018), the researches were conducted mainly from such perspectives as functional equivalence theory, relevance theory, interpretive theory or ecological translatology. Specifically, Liu (2017) based on relevance theory proposed that interpreting strategies for culture-loaded words include prediction strategy, context construction strategy, and fuzzy translation strategies. Sun (2017) from the perspective of functional equivalence theory, believed literal translation and free translation for idioms and allusions, literal translation and literal translation with comprehension, free translation method and substitution method for colloquial words, literal translation with comprehension and free translation method for the words with Chinese characteristics.

Since Chesterman (2012) pioneered translation memetics, he found five super memes, namely, "source-target" memes, "equivalence" memes, "untranslatability" memes, "free-vs-literal" memes and "all-writing-is-translating" memes. His study shed lights on the link between language and memes transmission, offering fresh thoughts for further studies. Of rare studies on the interpreting strategies of culture-loaded words from the perspective of linguistics memetics, the research (Zhang, 2015; Zhao, 2017) stood out in particular. Zhang (2015) concluded transliteration or literal translation for material culture-loaded words, religious culture-loaded and ecological culture-loaded words to become strong memes; free translation for social culture-loaded and linguistic culture-loaded words while translation criticism or paraphrases are improper for interpreting. Zhao (2017: pp. 145147) found three interpreting strategies of culture-loaded words, namely source meme imitation, target meme imitation and dynamic imitation.

However, the fact is that Zhang's research, poorly guided by linguistic memetics, thus giving limited suggestions for interpreters. While Zhao's research combined linguistic memetics and interpreting closely, he fails to offers practical suggestions for interpreters.

To put it in a nutshell, earlier studies were found three problems: research perspective, research subject and research method. On research perspective, linguistic memetics has been largely overlooked. On research subject, much has been largely confined to the field of translation, little mention of interpretation. On research method, the widely-used case analysis method led to less convincing research results.

Aiming at these problems, the present study based on corpus analysis, classifies culture-loaded words under the guidance of linguistic memetics and explores the interpreting strategies thereinafter.

\section{Methodology}

\subsection{Research Objectives}

As defined (Bao \& Bao, 2004: p. 10), culture-loaded words are known as the lex- 
ical gap means that no equivalent words can be found for cultural information carried by source words. Culture-loaded words, throughout this study, regarded as linguistic memes, are defined as "no equivalent memes available in the target language for the cultural information embodied in source memes".

The general objective of the present study, as stated clearly above, is to explore the interpreting strategies of culture-loaded words under the guidance of linguistic memetics and explore the interpreting strategies thereinafter.

In order to obtain this general objective, the following specific aims have been pursued:

- To define culture-loaded words and retrieve all qualified words in the 20172019 Premier's Press Conference at the "Two Sessions";

- To classify the culture-loaded words at the "Two Sessions" from the perspective of linguistic memetics;

- To explore the interpreting strategies of all the culture-loaded words at the "Two Sessions" from the perspective of linguistic memetics;

- To summarize the main interpreting strategies of each classification of culture-loaded words at the "Two Sessions".

\subsection{Data Collection}

With great influence, the Premier's Press Conference at the "Two Sessions" witness massive creation of culture-loaded words, which have been rarely studied yet. As a result of that, this present study selects the Premier's Press Conferences at the "Two Sessions" from three consecutive years (2017-2019) to deliver a more convincing and practical result.

The main data of this study come from the self-built corpus "Chinese-English Consecutive Interpreting Corpus of the 2017-2019 Premier's Press Conferences at the "Two Sessions". The origin of "Two Session" from 2017 to 2019 can be found on the following websites: http://www.kaosee.cn/plus/view.php?aid=8009; http://www.ethttp://www.etogether.net/htm/foreignAffairs/20180419/5174.html. This corpus is numbered 56,642 altogether, with the source text (ST) numbered 33,740 and the target text (TT) 22,902.

To retrieve culture-loaded words in the corpus, this paper, as defined before, regards culture-loaded words as linguistic memes with no equivalent memes available in the target language.

Under the guidance of that definition, this study picks out all qualified cultureloaded words one by one, thus obtaining the data basis for analysis. The culture-loaded words in the 2017-2019 Premier's Press Conference at the "Two Sessions" totals 103, with 35 in the year 2017, 34 in the year 2018, and 34 in the year 2019. A snapshot of culture-loaded words is like this (shown in Table 1).

\subsection{Research Stages}

An overview of research stages contained in the experimental part of this paper can be briefly summarized as follows: 
Table 1. A snapshot of culture-loaded words in the corpus.

\begin{tabular}{|c|c|c|}
\hline 2017 & 2018 & 2019 \\
\hline 靶向治疗 & 放管服 & 大水漫灌 \\
\hline 越组代庖 & 见端知本 & 夢卜快了不洗泥 \\
\hline 壮士断腕 & 天下大事必作于细 & 政贵有恒 \\
\hline 铁饭碗 & 动政府奶酪 & 稳定之针 \\
\hline 金饭碗 & 伤筋动骨 & 一竿子插到底 \\
\hline 大水漫灌 & 大盖帽 & 填窟窿 \\
\hline 硬着陆 & 抬杠 & 割自己的肉 \\
\hline 最后一公里 & 利民之事，丝发必兴 & 刀刃向内、 \\
\hline 万里长征图 & 万难不辞、万险不避 & 放水养鱼 \\
\hline 双创 & 两个毫不动摇 & 打白条 \\
\hline 放管服 & 新官不理旧账 & 放管服 \\
\hline 新旧嫁接 & 定心丸 & 鸟之两翼 \\
\hline 老树开新花 & 云多易生雨, 树大常招风 & 九二共识 \\
\hline 深港通 & 该翟的“脓包”还是要㪬 & 一揽子 \\
\hline 债港通 & 竹篮子也可以打水 & 卡脖子 \\
\hline 近水楼台先得月 & 马鞍形 & 十八般武艺 \\
\hline 扶上马、送－程 & 打“台湾牌” & 眼中有活 \\
\hline 有恒产者有恒心 & 大病致贫, 大病保险 & 后遗症 \\
\hline 选边站队 & 病来如山倒 & 打补丁 \\
\hline 养人 & 一锤子买卖 & “一老一小” \\
\hline $\begin{array}{c}\text { 用政府的“痛”换来 } \\
\text { 企业的“顺” }\end{array}$ & 小阳春 & 做文章 \\
\hline 工匠精神 & 乍暖还寒 & 痛点 \\
\hline 九二共识 & 硬着陆 & 热土 \\
\hline 赚大头 & 粤港澳大湾区 & 小微活、经济活 \\
\hline 蓝天保卫战 & 定盘星 & 抓大 \\
\hline 点赞 & 夕阳红 & 推小 \\
\hline 拉黑 & 政贵有恒 & 上天 \\
\hline 热土 & 牛鼻子 & 下地 \\
\hline 天下是天下人的天下 & 痛点 ( 风险点 ) & 管死 \\
\hline 奇萌 & 台独 & 堵点 ( 交汇点、分歧点) \\
\hline 刀刃向内 & 一巴掌打死 & 不明不白 \\
\hline 一国两制 & 港人治港 & 台独 \\
\hline 轻装上阵 & 澳人治澳 & 壮士断腕 \\
\hline 痛点 & 大病返贫 & 填窟犀 \\
\hline 台独 & & \\
\hline
\end{tabular}

- Integration of Premier's Press Conference at the "Two Sessions" for three consecutive years (2017-2019) with indication of ST and TT;

- Retrieval of qualified culture-loaded words in the corpus; 
- Classification of culture-loaded words from the perspective of linguistic memetics;

- Analysis of interpreting strategies of culture-loaded words;

- Summary of main interpreting strategies of each category of culture-loaded words classified before.

\section{Results and Discussion}

The results of the study are presented in this section. Sub-Section 4.1 focuses on the classification of culture-loaded words in the sub-corpus from the perspective of linguistic memetics. The next Section-4.2 deals with the interpreting strategies adopted in the whole corpus. Finally, in Section 4.3, a summary will be made with regard to the main interpreting strategies of each category of culture-loaded words classified before.

\subsection{Classification of Culture-Loaded Words in the ST Corpus}

The present study, classifies culture-loaded words in the sub-corpus into three categories according to their representation information and content: form-meaning compound culture-loaded words (FMCWs), pronunciation derived cultureloaded words (PDWs) and culture-loaded words derived from morphological structures (MSDWs).

Specifically, FMCWs refer to the culture-loaded words with strong reproduction ability both in language form and content, including general terms used in a certain period, idioms, set phrases, proverbs, etc. In the sub-corpus, such words are “壮士断腕”, “近水楼台先得月”, “赚大头”, “抬杜”. PDWs refer to those culture-loaded words formed by transferring different contents while replicating the phonetic form of a specific language unit or discourse unit. It is shown in the level of words, phrases, sentences and discourses such as “大水漫灌”, “定心丸”, “点赞”, “拉黑”. refer to those culture-loaded words created by replicating structure formation of specific language units or discourse units. The structure formation copied can be a pattern of words, phrases, sentences, discourses, etc. to transfer different contents such as “金饭碗”, “铁饭碗”, “蓝天保卫战”. FMCWs, PDWs and MSDWs in the sub-corpus, present different frequencies shown in the following.

From Figure 1, the proportion of FMCWs, PDWs, and MSDWs is $48 \%, 37 \%$, and $15 \%$ respectively. Specifically, the proportion of FMCWs takes almost half of the total, over three times the MSDWs and 11\% more than the PDWs. This boils down to the fact that both PDWs and MSDWs are derived from FMCWs.

\subsection{Interpreting Strategies of Culture-Loaded Words}

The present study, after a meticulous analysis, finds that five interpreting strategies adopted in the whole corpus: source meme imitation (SMI), target meme imitation (TMI), dynamic imitation (DI), omission (OM) and source meme imitation plus explanation (SMIPE). Except SMIPE, other four strategies are applied in FMCWs, PDWs and MSDWs. Since each interpreting strategy has its own scope of application and applied condition, SMIPE is only applied to FMCWs and 


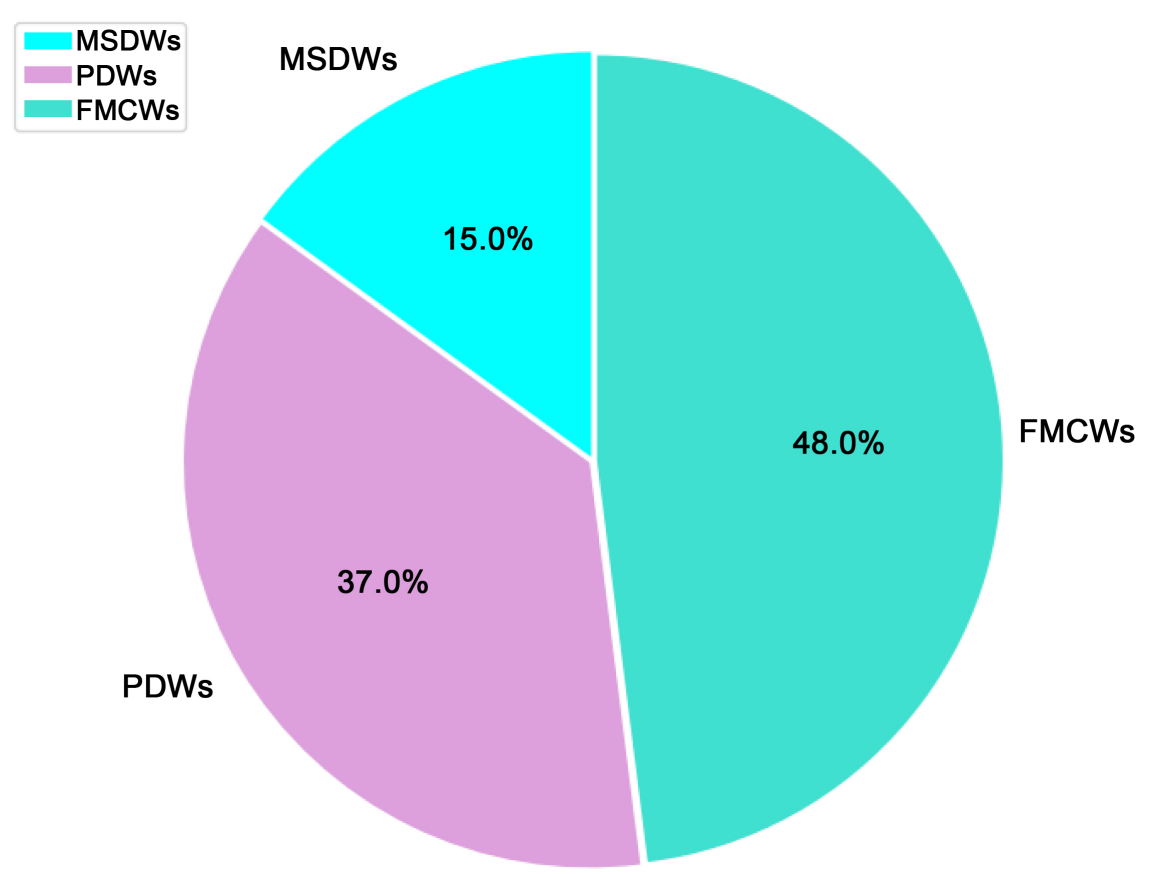

Figure 1. Proportion of three categories of culture-loaded words.

MSDWs. The following five examples show the application of these five interpreting strategies from the perspective of linguistic memetics.

Example (1): 这些都是动政府 “奶酪” 的, 是伤筋动骨的改革。

TT: we are making profound adjustments to government functions. This is like moving the government's own cheese.

“奶酪” in Chinese, a fermented milk product, is an important daily food. Here, it has its meaning changed. It has become a super meme as for the improvement of the people's well-being or streamlining government functions. Interpreted by SMI, "cheese" presents not only vivid image but accords with the "Language's Economic Principle" ${ }^{1}$ (LEP).

Example (2): 如果说赚钱的话, 我想欧洲企业在中国不仅有钱可赚, 而且 还是赚大头。

TT: Talking about profits, I think European companies have not just earned profits in China but have also taken the lion's share of such profits.

“赚大头” is a regional dialect with distinct linguistic characteristics, which would certainly baffle the target audience. It means taking the most part of the money. Exactly, there is an equivalent target meme in the TL. The phrase "take the lion's share" is frequently used in foreign media and thus becomes a super meme in the TL. By imitating this strong meme in the TL, the interpreter manages to achieve similar pragmatic effect.

Example (3): 该翟的 “脓包” 还是要翟, 否则也有道德风险。

TT: When a blister needs bursting, it should be burst.

“脓包” refers to a swelling formed in the skin after it is infected. Here, that

${ }^{1}$ Martinet (1962) proposed that human beings always expect to disseminate information with the least labor on the premise that smooth communication is ensured. 
meaning has been changed and the pronunciation is loaned. If interpreted by SMI strategy into "pustule", it could baffle the target audience that this illness is supposed to be removed instead of being burst. However, the expressive effect would be lost if under TMI strategy into "a serious risk". For that reason, the interpreter needs to accommodate the expression mode and linguistic form. In that sense, "blister" is easy for the target audience to catch the meme and decode it.

Example (4): 不仅是审批权, 还有名目繁多的行政许可, 资格认证, 各种 奇苑证明。

TT: In addition to government review and approval items, there are all sorts of procedures requiring administrative permits, certification of qualifications.

“奇薢” in Chinese has various meanings. It originally refers to exotic flower or extraordinarily beautiful flower, and something breathtakingly beautiful. It has evolved into a buzzword particularly someone or something unusual or weird. The property of this word is shown in both commendatory and derogatory sense. Here, it means unusual or unacceptable qualifications, overlapping “名目 繁多”, and thus is omitted.

Example(5): 你们可能也都记得, 在前几年两会上, 曾有人展示了一个项目 审批 “万里长征图”。

TT: You may remember that a few years ago, a delegate at the Two Sessions produced a so-called Long-March matrix, showing all the intricate procedures for administrative approval.

“万里长征” is a historic event in our history. It refers to the long march of twenty-five thousand-li made by the Chinese Red Army. “万里长征图” here is also called a map of approval process, with a length of 8 meters, covering government review, administrative permits, and others for 995 working days before getting the project approved. Since "Long March" is not unfamiliar with the target audience, it is easy to be assimilated. Nonetheless, “万里长征图” is hard to be connected with administrative approval. Therefore, the hidden cultural information in this metaphor is needed to be explained. "showing all the intricate procedures" would easily reach the understanding of the target audience.

Of the frequencies of culture-loaded words adopting SMI, TMI, DI, OM and SMIPE, TMI takes the lion's share:

As seen from Figure 2, the proportion TMI stands at $38.8 \%$, SMI at $30.1 \%$, DI $11.7 \%$, OM $15.5 \%$ and SMIPE $3.9 \%$. As we discussed before, TMI is to imitate the target memes in the TL which has similar content as that of the source memes. According to linguistic memetics, TMI imitates super memes in the TL, which spares much effort for the audience to decode and to be "infected". That bolsters the expression period in which the audience may express and transmit them in various forms.

\subsection{Main Interpreting Strategies of FMCWs, PDWs and MSDWs}

The five interpreting strategies: SMI, TMI, DI, OM and SMIPE, each with different 


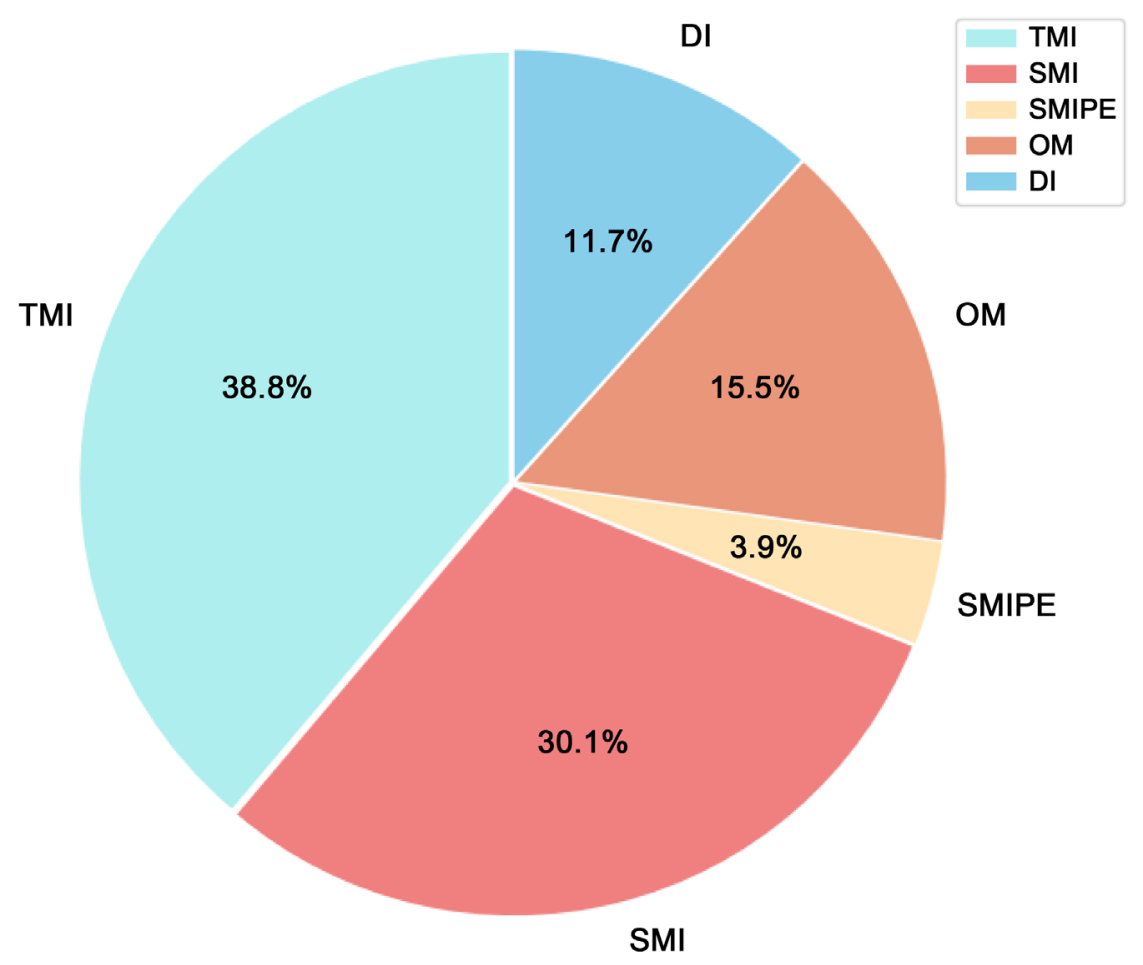

Figure 2. Proportion of five interpreting strategies.

scope of application as well as applied conditions. As for the application in the interpreting practice, a general law would spare much effort and lower pressure for interpreters. For that matter, this part focuses on exploring the main interpreting strategies. It is hoped to provide a general law for the benefit of the interpreter in the interpreting of culture-loaded words in the live interpreting. The proportions of interpreting strategies in FMCWs, PDWs and MSDWs are shown respectively below:

From Figure 3, five interpreting strategies are applied to FMCWs, with TMI takes the largest proportion of $42.2 \%$, followed by SMI of $26.5 \%$, DI $13.7 \%$, OM $11.8 \%$ and SMPE $5.9 \%$. TMI accounts for nearly half of the total, and SMI nearly one-third. The main interpreting strategies of FMCWs are TMI and SMI. According to linguistic memetics, FMCWs present stable linguistic content and form, making it hard to find equivalent target memes in the TL. That's the very reason that the interpreter resorts to TMI strategy.

As shown in Figure 4, five interpreting strategies are applied to PDWs, with TMI takes the biggest proportion of $34.0 \%$, and SMI takes the second place of $29.0 \%$, with OM reaching $24.5 \%$, DI $8.0 \%$, and SMIPE 5.0\%. The main interpreting strategies of PDWs are TMI, SMI and OM. According to linguistic memetics, some cultural memes of PDWs in the SL show unstable content which may vary in different linguistic environment. Nonetheless, they present strong adaptability due to their pronunciation. Therefore, the interpreter needs to have a correct understanding of the culture memes of PDWs in the SL, and to combine linguistic context to decide which strategy is suitable. 


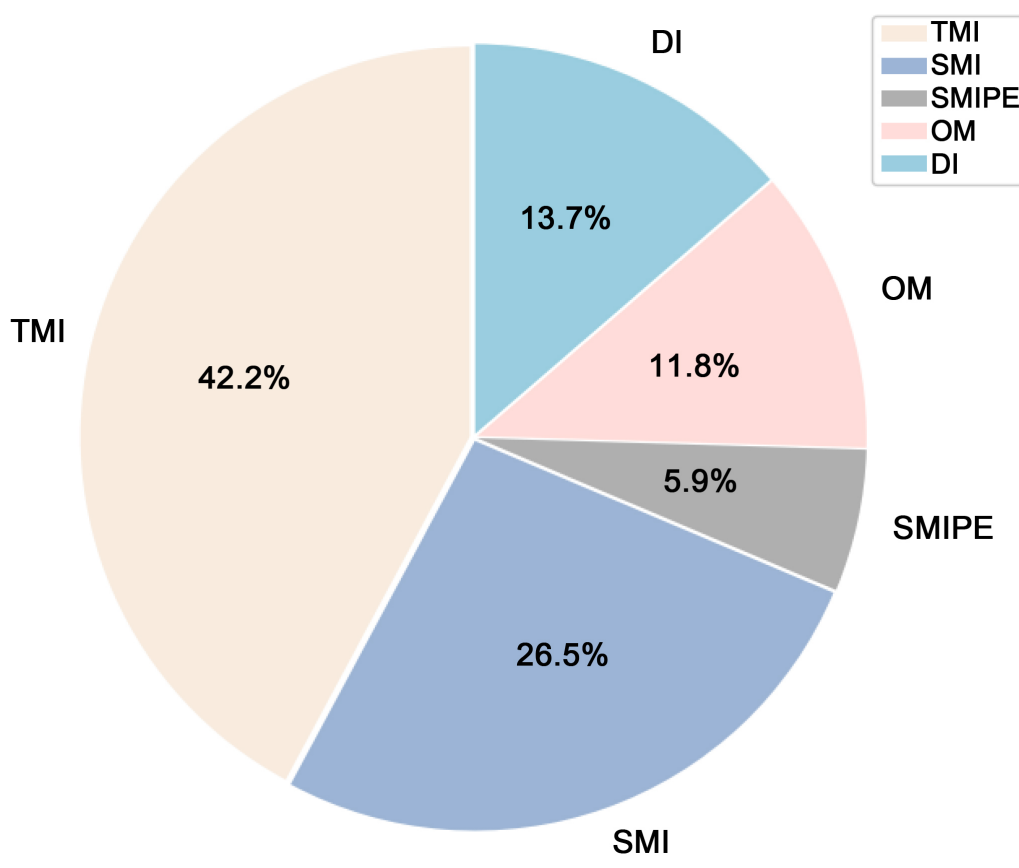

Figure 3. Proportion of interpreting strategies of FMCWs.

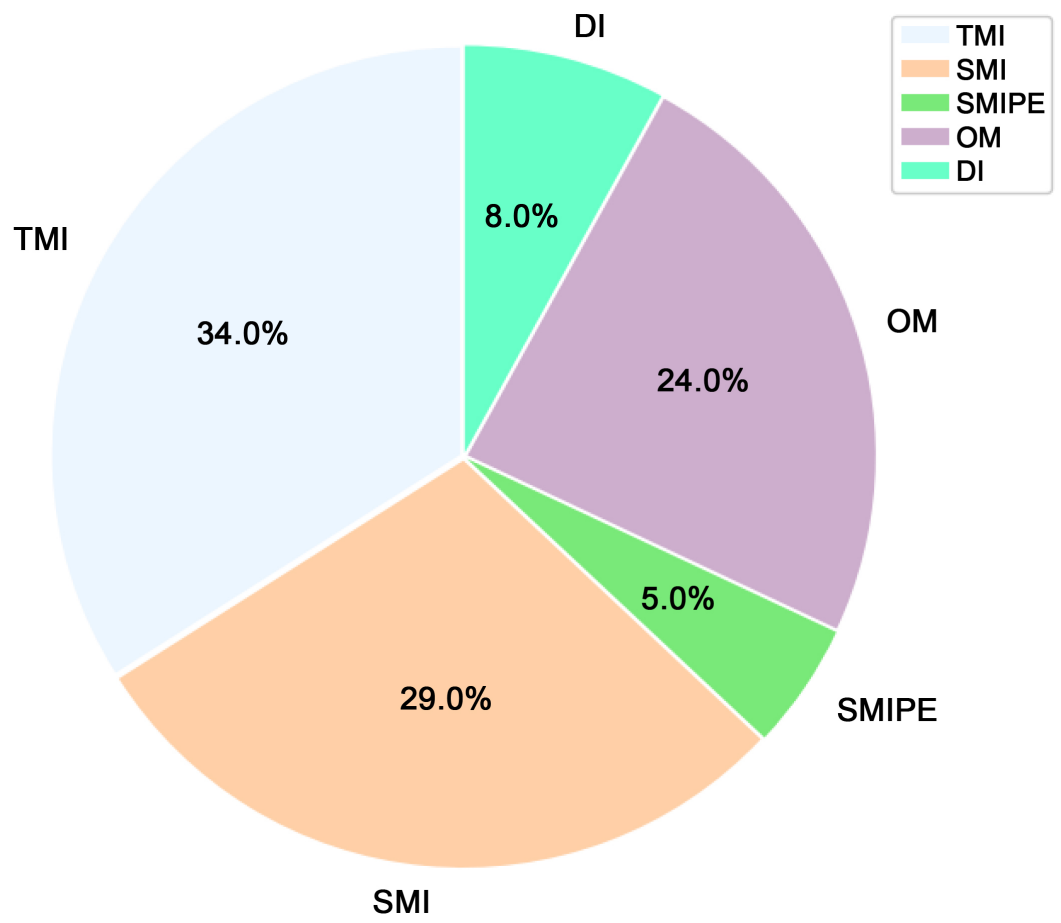

Figure 4. Proportion of interpreting strategies of PDWs.

As seen from Figure 5, only four interpreting strategies are applied in MSDWs: SMI, TMI, OM and DI. Specifically, SMI takes the biggest proportion of $44.0 \%$, and TMI takes the second place of $37.0 \%$, with DI standing at $13.0 \%$, OM at $6.0 \%$. The main interpreting strategies of MSDWs are SMI and TMI. According to linguistic memetics, MSDWs are derived from those FMCWs with stable meaning 


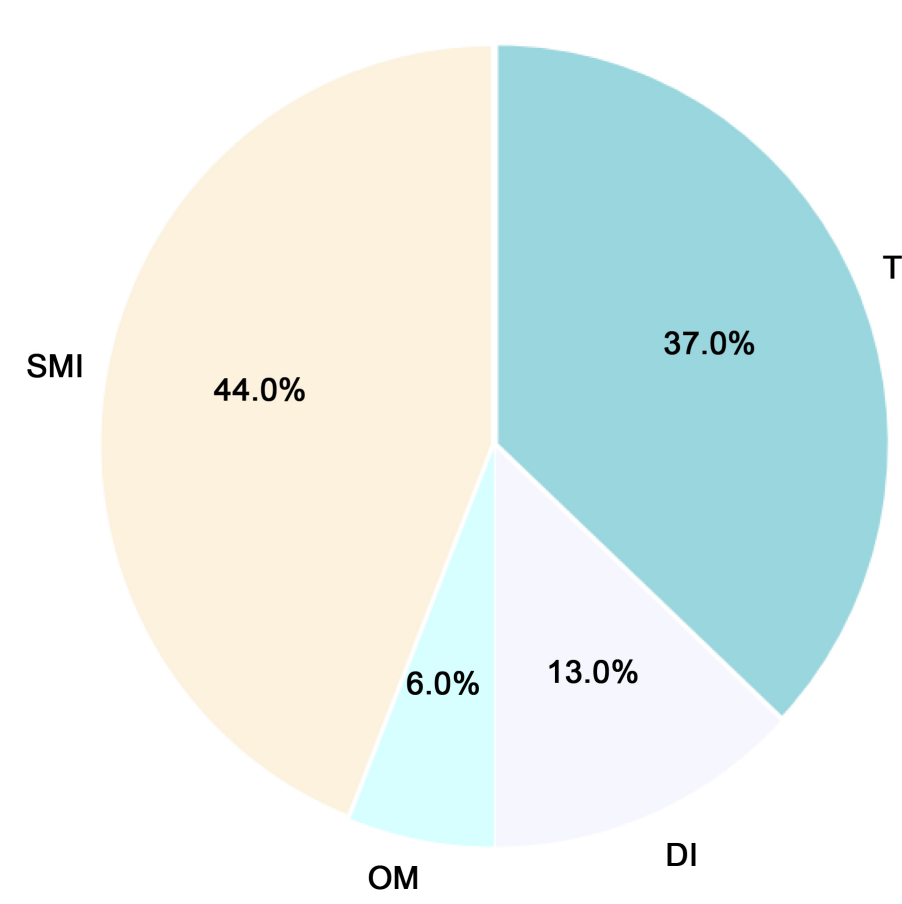

Figure 5. Proportion of interpreting strategies of MSDWs.

and vivid linguistic form. By imitating the structure, MSDWs also can find their presence in the target memes. Therefore, SMI strategy is available.

Of the five interpreting strategies, SMIPE and DI cost the interpreter much more time and is less frequently used. TMI and SMI enjoy high rate of adoption. DI cost time, though, it maximizes the reflection of source memes which vary with different environment. That facilitates assimilation of source memes. Furthermore, it strives to foster the expression of target memes in the TL in a variety of forms such as articles, films, speeches, etc. In the live interpreting practice, the interpreter is required to understand the source memes, to master the target memes in the TL, to accommodate the clout of cultural elements and acceptability of the target audience, and to combine the context and factors affecting the transmission of memes, striving to produce the same effect on the TL audience as was produced by the original on the SL audience (Newmark, 2001). Through such effort, the interpreter enables source memes to gain productive force in the TL and in the final analysis facilitates cross-cultural communication.

\section{Concluding Remarks}

With increasing exchanges and integration between different cultures under the ear of globalization, the interpreting of culture-loaded words cannot be more relevant. As stated by Venuti (1995) that translators are urged to think of new ways to make their work "invisible". The present study, under the guidance of linguistic memetics, classifies culture-loaded words into three categories: FMCWs, PDWs and MSDWs, and discovers five interpreting strategies: SMI, TMI, DI, OM and SMIPE, each with its own application scope. As expected, the SMI strategy may 
heed the call for the foreigners' growing desire for learning more exotic cultures. Nonetheless, the role of the TMI in building a bridge between two cultures at the very beginning cannot be overlooked. Under that circumstances, the interpreter is required to maximize the reflection of source memes to facilitate the assimilation period during the transmission period, and to find equivalent or similar memes in the TL in cross-cultural communication.

The present study has both theoretical and practical significance. Theoretically, it expands the application field of linguistic memetics beyond earlier studies largely confined to translation filed. In that sense, it is a new attempt to promote the application of linguistic memetics to interpreting researches. Practically, this study classifies culture-loaded words from the perspective of linguistic memetics, offering insight into closer link between language and meme. Furthermore, the interpreting strategies, explored and summarized based on the corpus analysis method, are therefore more convincing and representative, offering targeted and practical suggestions for interpreters, and implications for future studies in this regard.

However, the present study is limited in scope, for the ill consideration to all possible situations where linguistic memes may vary with different living environments. Further studies are suggested to draw on linguistic memetics to dig up increasing presence of MSDWs and wider application of TMI and DI interpreting strategy in cross-cultural communication and explore them beyond consecutive interpreting.

\section{Acknowledgements}

The author wishes to acknowledge support from the project of business English construction under "Four Ones" Construction Project of Nanchang Vocational University (No. 20200922) and the project of Teaching Team Construction for Business English Major Construction under "Four Ones" Construction Project of Nanchang Vocational University (No. 20200923).

\section{Conflicts of Interest}

The author declares no conflicts of interest regarding the publication of this paper.

\section{References}

Baker, M. (2000). In Other Words: A Coursebook on Translation. Foreign Language Teaching \& Research Press.

Bao, H. N., \& Bao, A. (2004). Chinese Culture and Chinese-English Translation (p. 10). Foreign Language Press.

Bassnett, S., \& Lefevere, A. (1990). Translation, History, and Culture: A Sourcebook. Shanghai Foreign Language Education Press.

Blackmore, S. (1999). The Meme Machine. Oxford University Press.

Blackmore, S. (2000). The Power of Memes. Scientific American, 4, 52-61. https://doi.org/10.1038/scientificamerican1000-64

Chen, Q. M. (2010). On the Translation of Culture-Loaded Words in English News. Ca- 
nadian Social Science, 5, 164-165.

Chesterman, A. (2012). Memes of Translation: The Spread of Ideas in Translation Theory. Shanghai Foreign Language Education Press.

Dawkins, R. (1976). The Selfish Gene. Oxford University Press.

Dawkins, R. (1981) In Defense of Selfish Genes. Philosophy, 218, 556-573. https://doi.org/10.1017/S0031819100050580

Dennett, D. C. (1990) Memes and the Exploitation of Imagination. The Journal of Aesthetics and Art Criticism, 2, 127-135. https://doi.org/10.1111/1540 6245.jaac48.2.0127

Distin, K. (2014). The Selfish Meme. World Book Publishing Corporation.

Fan, X. (2018). On C-E Translation of Culture-Loaded Words from the Perspective of Relevance Theory. M.D. Thesis, China University of Geosciences.

Gile, D. (1995). Basic Concepts and Modes for Interpreter and Translator Training. John Benjamins Publishing Company. https://doi.org/10.1075/btl.8(1st)

Guo, X. M. (2011). On the English Translation of Chinese Culture-Loaded Words in the Context of Globalization from the Perspective of Eco-Translatology. Journal of Central South University of Forestry \& Technology (Social Sciences), 3, 73-75.

He, Z. R. (2017). Linguistic Memes and Ecology of Public Sphere. Foreign Languages in China, 3, 22-29.

He, Z. R. et al. (2007). New Developments in Pragmatics: Relevance, Adaption and Memetics. Shanghai Foreign Language Education Press.

He, Z. R. et al. (2014). Linguistic Memetics: Theory and Adaptation (pp. 6-95). Jinan University Press.

Hermans, T. (2004). Translation in Systems: Descriptive and System-Oriented Approaches Explained. Shanghai Foreign Language Education Press.

Heylighen, F. (1992). "Selfish" Memes and the Evolution of Cooperation. Journal of Ideas, 4, 77-84.

Huang, X., \& Yan, X. Y. A. (2018). Comparative Study of English Versions of Sakya Maxim-Culture-Loaded Words from the Perspective of Communication Studies. Tibetan Studies, 3, 159-167.

Ji, K., \& Shi, Y. (2010). Translator's Position and Translation of Culture-Loaded WordsThree English Versions of Real Story of Ah Q. Academic Forum, 12, 225-230.

Li, N. (2017). Culture-Loaded Words in the Return of a Dream of Red Mansions from the Perspective of Intertextuality Theory. Journal of Mudanjiang University, 7, 100-102.

Liu, Y. (2017). A Practical Report on Cultural-Loaded Words Interpretation under the Guidance of Relevance Theory. M.D. Thesis, Central China Normal University.

Martinet, A. (1962). A Functional View of Language. Clarendon Press.

Newmark, P. (2001). Approaches to Translation. Shanghai Foreign Language Education Press.

Nida, E. A. (1998). Language Culture and Translating. Standards Press of China.

Shiryaeva, V., \& Badea, G. L. (2014). Subtitling: The Transfer of Culture-Specific Words in a Multidimensional Translation. Procedia-Social and Behavioral Sciences, 149, 883888. https://doi.org/10.1016/j.sbspro.2014.08.270

Song, H. (2012). Interpretation of Chinese Culture-loaded Words from the Perspective of Relevance Adaptation. M.D. Thesis, Xiamen University.

Sun, Z. H. (2017). Interpreting Strategies of Culture-Loaded Words from the Perspective of Functional Equivalence Theory. M.D. Thesis, Heilongiiang University.

Tomalin, B., \& Stempleski, S. (1994). Cultural Awareness. Oxford University Press. 
Toury, G. (1995). Descriptive Translation Studies and Beyond. John Benjamins Publishing Company. https://doi.org/10.1075/btl.4

Venuti, L. (1995). The Translation's Invisibility: A History of Translation. Shanghai Foreign Language Education Press.

Wang, J. J., \& He, L. (2014). An Analysis of Mongolian Culture-Loaded Words and Their Translation Strategies. Higher Education Studies, 4, 91-96. https://doi.org/10.5539/hes.v4n2p91

Wang, H. Y., \& Yu, G. F. (2011). Meme Communication and Domestication and Foreignization of Translation. Social Scientist, 8, 150-152.

Yao, X. F. (2013). Translation of Culture-Loaded Words in Tang Poetry. Journal of Shanxi Normal University (Social Science Edition) A, 4, 105-106.

Ye, Y. T. (2018). A Study on E-C Translation Method of Culture-Loaded Words from the Perspective of Memetics-A Case Study of the Book of Songs by Xu Yuanchong. M.D. Thesis, Xihua University.

Zhang, S. Y. (2015). On Interpretation Strategies of Chinese Culture-Loaded Words from the Perspective of Memetics. M.D. Thesis, Jinlin University.

Zhao, S. (2017). Interpretation Studies and Practices (pp. 133-147). Guangming Daily Press.

Zhe, Z. (2017). On C-E Translation of Culturally-Loaded Words from a Literary Perspective. Academics in China, 6, 305-314.

Zhu, Y. M. (2018). Interpreting Strategies of Culture-Loaded Words in Press Conference from the Perspective of Interpretation Theory. M.D. Thesis, Guangdong University of Foreign Studies. 